Dhaka Univ. J. Biol. Sci. 20(2): 173-182, 2011 (July)

\title{
PHYSICO-CHEMICAL CHARACTERISTICS OF THE SEASONALLY FLOODED SOILS OF BANGLADESH AND THEIR MANAGEMENT IMPLICATIONS
}

\author{
K. F. AKter, Z. H. Khan*, M. S. Hussain and A. R. Mazumder \\ Department of Soil, Water and Environment, University of Dhaka, Dhaka-1000, Bangladesh \\ Key words: Seasonally flooded soils, Physical and chemical attributes, Management \\ implications
}

\begin{abstract}
The seasonally flooded soils of Bangladesh are unique in respect of several specific characteristics and contribute toward producing bulk of its staple food mainly rice. Having fine texture these soils are similar to the "paddy soils" of Southeast Asian floodplains and have high production potential under proper management. Six representative soil series, viz. Arial, Debidwar, Naraibag, Jalkundi, Siddirganj and Tippera from the central region of Bangladesh have been studied to evaluate some of their intrinsic physico-chemical properties and their sustainable management requirements. These soils are slightly acidic to neutral and are negatively charged with $\Delta \mathrm{pH}$ values ranging between -0.2 and -1.2 . The organic matter content in the surface soil is relatively low that decreases steadily with depth. The cation exchange capacity (CEC) of the soils varies on the basis of their clay and organic matter contents while base saturation per cent (BSP) is high. The contents of available N, P, K and S and DTPAextractable $\mathrm{Fe}, \mathrm{Mn}, \mathrm{Cu}$ and $\mathrm{Zn}$ in soils are moderate and are commensurate with the contents of colloidal fractions. These soils receive several mineral nutrients annually with the sediments deposited during the monsoon floods. The characteristics like organic matter content, particle size distribution, CEC, $\mathrm{pH}$ and BSP that have important management implications have been discussed.
\end{abstract}

\section{Introduction}

The flat deltaic region of the Ganges-Brahmaputra-Meghna (GBM) river system occupies the larger part of Bangladesh and around one-fourth of these flat lands are seasonally flooded during the monsoon to variable depths and durations. The seasonally flooded areas of Bangladesh as per Ramsar Convention are categorized as wetlands(1) and soils of these wetlands have been categorized as surface-water gley soils(2), aquorizems ${ }^{(3)}$ and gray hydromorphic soils. ${ }^{(4)}$ These soils are aquic/udic in respect of moisture regime and cultivation of paddy - both local and HYVs - are the major land uses that support over 160 million people in Bangladesh. ${ }^{(5)}$ These soils in the past, though were considered as fertile for growing traditional wetland crops without using agro-chemicals, but for growing HYVs require variable doses of chemical fertilization at the present time. Under

\footnotetext{
*Coresponding author. <khanzh_du@yahoo.com>.
} 
the changed situation it is, therefore, essential that the intrinsic properties of these soils are determined accurately and evaluated carefully in an effort to stabilize the sustained agricultural productivity of these soils. There are innumerable examples in history that due to lack of adequate knowledge and improper uses the seasonally flooded floodplain soils in the past centuries became degraded and unproductive causing disappearance of many civilizations.

The seasonally flooded soils of Bangladesh are characterized by excess water in the monsoon and very little in the dry season. The seasonal flooding of soils is considered as a natural phenomenon which is caused either by rain water or by river water or by both or by standing irrigation water in rice fields. The heavy monsoon rainfall in Bangladesh comes at a time when the major rivers bring in a large volume of water from their upper reaches that causes flooding on the floodplains. Around 23\% of the area of Bangladesh is routinely flooded every year for varying periods. ${ }^{(6)}$ Land in Bangladesh has been divided into five inundation land types.(5) Seasonally flooded soils undergo the following developmental stages: initial deposition of alluvium, ripening, formation of mottles, homogenization, development of structure, formation of flood coating, changes in subsoil reaction, ferrolysis, formation of gleyans and formation of ploughpan.(5) On submergence many physico-chemical and chemical properties of soils undergo both reversible and irreversible changes.(7) The floodplain soils in Bangladseh have undergone seasonal flooding for many hundreds of years. Because of their location in the tropics high temperature and abandunt moisture result in stronger pedochemical weathering and quicker soil profile development. (5)

Authors of this paper intent to highlight the phygico-chemical characteristics of several representative seasonally flooded soils developed in the central region of Bangladesh for determining their abilities to maintain sustainable productivity for its fast growing population.

\section{Materials and Methods}

The study area covers over a million hectare in the central hydro-ecological region of Bangladesh. Soil samples for the study have been collected from river alluvia of the GBM system. Locations of the sampling sites are shown in Fig. 1 and the parent materials, cropping pattern and taxonomic classification of soil series are presented in Table 1. The exact locations of the selected pedons were determined with GPS and were shown in the above figure. A total of 30 soil samples were collected from six pits on natural horizon basis. The soil samples were duly processed, preserved and analyzed for determination of their physico-chemical characteristics. The morphological and chemical properties of the studied soils have also been discussed.(8) The annual flooding characteristics, subsoil horizon, plough-pan, flood coatings, matrix colour and mottles and consistence are the notable morphological features relevant to the management of these soils. ${ }^{(8)}$ 


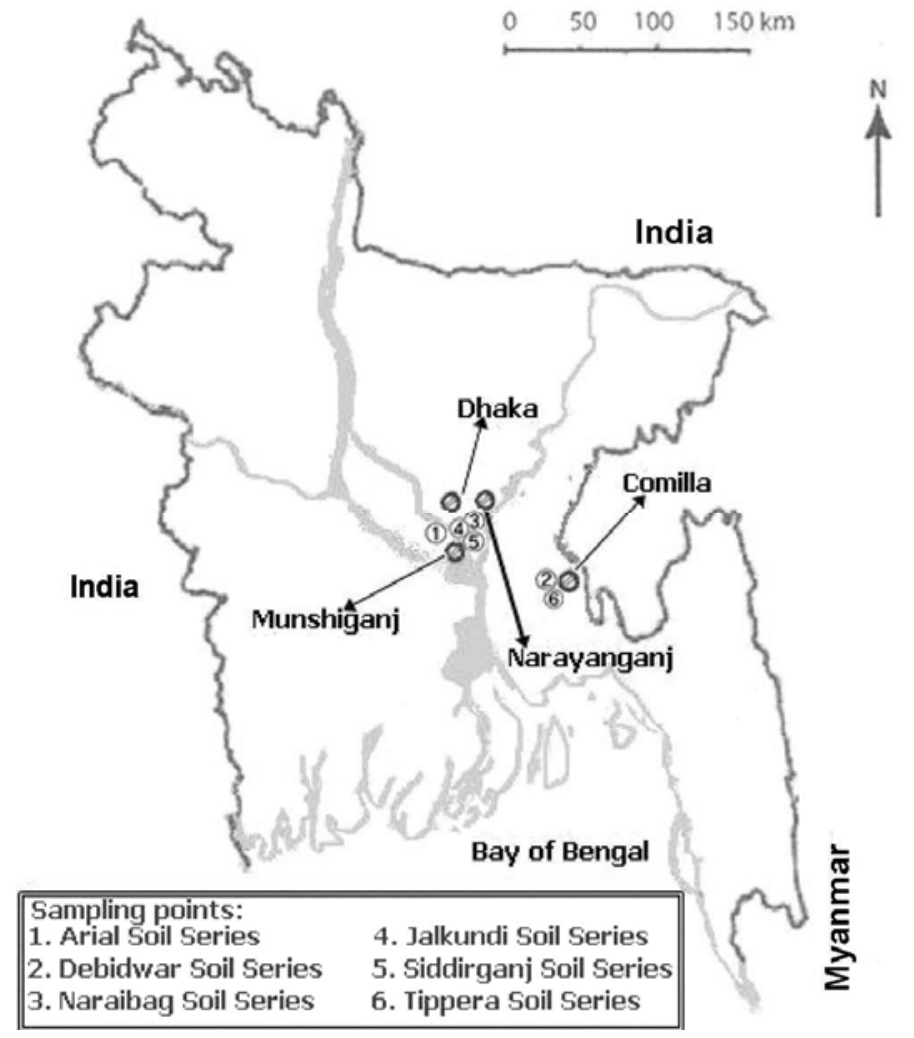

Fig. 1. Location map of the study area showing soil sample sites.

Table 1. Location and classification of some representative seasonally flooded soils.

\begin{tabular}{|c|c|c|c|c|}
\hline $\begin{array}{l}\text { Soil } \\
\text { series* }\end{array}$ & $\begin{array}{l}\text { Location } \\
\text { (Latitude and } \\
\text { Longitude) }\end{array}$ & $\begin{array}{l}\text { Parent } \\
\text { material }\end{array}$ & $\begin{array}{l}\text { Landuse/ } \\
\text { cropping pattern }\end{array}$ & $\begin{array}{l}\text { Soil clasification** } \\
\text { (Subgroups) }\end{array}$ \\
\hline Arial & $\begin{array}{l}\text { Srinagar upazila } \\
23^{\circ} 25^{\prime} \mathrm{N} \& 90^{\circ} 15^{\prime} \mathrm{E}\end{array}$ & $\begin{array}{l}\text { Ganges river } \\
\text { alluvium }\end{array}$ & Boro-fallow & Vertic Endoaquept \\
\hline Debidwar & $\begin{array}{l}\text { Chandina upazila } \\
23^{\circ} 24^{\prime} \mathrm{N} \& 91^{\circ} 02^{\prime} \mathrm{E}\end{array}$ & $\begin{array}{l}\text { Meghna river } \\
\text { aluvium }\end{array}$ & $\begin{array}{l}\text { Boro-fallow/ } \\
\text { T. aman }\end{array}$ & Aeric Endoaquept \\
\hline Jalkundi & $\begin{array}{l}\text { Rupganj upazila } \\
23^{\circ} 45^{\prime} \mathrm{N} \& 90^{\circ} 32^{\prime} \mathrm{E}\end{array}$ & $\begin{array}{l}\text { Meghna river } \\
\text { alluvium }\end{array}$ & T. aman-fallow & Aeric Endoaquept \\
\hline Naraibag & $\begin{array}{l}\text { Rupganj upazila } \\
23^{\circ} 45^{\prime} \mathrm{N} \& 90^{\circ} 31^{\prime} \mathrm{E}\end{array}$ & $\begin{array}{l}\text { Brahmaputra } \\
\text { alluvium }\end{array}$ & $\begin{array}{l}\text { Boro-fallow- } \\
\text { T. aman }\end{array}$ & Aeric Endoaquept \\
\hline Siddirganj & $\begin{array}{l}\text { Rupganj upazila } \\
23^{\circ} 35^{\prime} \mathrm{N} \& 90^{\circ} 30^{\prime} \mathrm{E}\end{array}$ & $\begin{array}{l}\text { Mixed Meghna } \\
\text { and Brahmaputra } \\
\text { river alluvium }\end{array}$ & B. aman-fallow & Typic Endoaquept \\
\hline Tippera & $\begin{array}{l}\text { Debidwar upazila } \\
23^{\circ} 30^{\prime} \mathrm{N} \& 91^{\circ} 01^{\prime} \mathrm{E}\end{array}$ & $\begin{array}{l}\text { Meghna river } \\
\text { alluvium }\end{array}$ & $\begin{array}{l}\text { Rabi and kharif } \\
\text { vegetables }\end{array}$ & Typic Epiaquept \\
\hline
\end{tabular}

Source: *SRDI Staff ${ }^{(15)} ;{ }^{* *}$ Soil Survey Staff. $\left.{ }^{24}\right)$ 
The particle size analysis of soils has been carried out by sieving and using hydrometer method as per Gee and Bauder.(9) The $\mathrm{pH}$ determination has been done using glass electrode in soil suspensions in $\mathrm{H}_{2} \mathrm{O}$ and $1 \mathrm{M} \mathrm{KCl}$. The $\Delta \mathrm{pH}$ was calculated by subtracting $\mathrm{pH}$ in $\mathrm{H}_{2} \mathrm{O}$ values from $\mathrm{pH}$ in $\mathrm{KCl}$ values. Organic carbon was determined by Walkley and Black ${ }^{(10)}$ wet oxidation method and total nitrogen was estimated by digestion of the soil in the sulfuric acid followed by a Kjeldahl distillation. ${ }^{(11)}$ CEC was measured leaching the soil sample with neutral $1 \mathrm{~N}$ ammonium acetate solution ${ }^{(12)}$ and exchangeable bases were determined from the same $1 \mathrm{~N}$ ammonium acetate leachate using atomic absorption spectrophotometer. Available N, P, K and S have been determined using standard volumetric and colorimetric procedures.(13) Determination of available $\mathrm{Fe}, \mathrm{Mn}, \mathrm{Cu}$ and $\mathrm{Zn}$ was done from DTPA- $\mathrm{CaCl}_{2}$ extracts using atomic absorption spectrophotometer.(14)

\section{Results and Discussion}

The sand fraction in the studied soils varies from 2 to 25 per cent while the silt fraction ranges from 23 to 60 per cent showing a mean value of 41 per cent (Table 2). The high clay content (21 to 73 percent with a mean value of 45 per cent) of the studied soils is indicative of their favourable agricultural use potential. The rather erratic vertical distribution of particle size components indicate the heterogeneity and lithological discontinuity of the sediments and the turbulent condition under which they were deposited. The silt/clay ratio in many horizons varied erratically (0.31 to 2.67$)$ and indicated that the observed variation of silt/clay ratio is lithological rather than weathering of silt into clay in situ. The sand/silt ratio of the soils is less than 1.0 with a mean value of 0.34 .

The soils under study being fine-textured show textural variations ranging from silt loam to clay (Table 2). The Tippera series occurring on floodplain ridges is texturally lighter while the Debidwar, Arial, Jalkundi, Naraibag and Siddirganj series occurring on basin margins and bottoms are texturally finer. In general the ridge soils have silt loam to silty clay loam texture while the basin soils are clayey. ${ }^{(5,15)}$

The data in Table 3 show the $\mathrm{pH}$ (water) value of soils range from 5.4 - 7.0. The $\mathrm{pH}$ values show increasing trends with the increase of depth a feature common in the seasonally flooded/saturated soils of Bangladesh. ${ }^{(5)}$ Brinkman $^{(2)}$ working with several surface-water gley soils of Bangladesh that are subject to seasonal flooding and droughtiness cause seasonal $\mathrm{pH}$ fluctuation in surface horizon that break down the clay lattice releasing the silicon and sesquioxides in which the pedogenic feature was termed by him as ferrolysis. An observed decline of $\mathrm{pH}(1 \mathrm{~N} \mathrm{KCl})$ in all the soils and the $\Delta \mathrm{pH}$ values are presumed to be due to the difference in reserve acidity.

Organic matter contents in the surface horizons of the studied soils ranged from 1.76 to 2.05 per cent that decreased steadily with depth (Table 3). The variation in organic matter content in different horizons of hydromorphic soils is used as a criterion in 
defining the Cambic horizon in soil taxonomy. The organic matter content in surface and subsurface horizons remains in equilibrium with the prevailing environmental components particularly the land use of a region. Under Bangladesh condition, the organic matter content in the surface soil drops abruptly down with the change of land use from forestry to agriculture.

Table 2. Particle size distribution and textural classes of some seasonally flooded soils from Bangladesh.

\begin{tabular}{|c|c|c|c|c|c|c|c|c|}
\hline \multirow[t]{2}{*}{ Soil Series } & \multirow[t]{2}{*}{ Horizon } & \multirow[t]{2}{*}{$\begin{array}{l}\text { Depth } \\
(\mathrm{cm})\end{array}$} & \multicolumn{3}{|c|}{$\begin{array}{l}\text { Particle size distribution } \\
(\%)\end{array}$} & \multirow[t]{2}{*}{$\begin{array}{l}\text { Textural } \\
\text { class }\end{array}$} & \multirow[t]{2}{*}{$\begin{array}{l}\text { Sand } / \text { silt } \\
\text { ratio }\end{array}$} & \multirow[t]{2}{*}{$\begin{array}{l}\text { Silt/clay } \\
\text { ratio }\end{array}$} \\
\hline & & & Sand & Silt & Clay & & & \\
\hline \multirow[t]{4}{*}{ Arial } & Apg & $0-20$ & 3 & 27 & 70 & clay & 0.11 & 0.39 \\
\hline & $\mathrm{B} 2 \mathrm{~g}$ & $20-60$ & 4 & 23 & 73 & clay & 0.09 & 0.31 \\
\hline & B3g & $60-100$ & 2 & 31 & 67 & clay & 0.06 & 0.46 \\
\hline & $\mathrm{IICg}$ & $100+$ & 8 & 27 & 65 & clay & 0.30 & 0.42 \\
\hline \multirow[t]{5}{*}{ Debidwar } & Apg & $0-12$ & 8 & 60 & 32 & silty clay loam & 0.13 & 1.88 \\
\hline & B1g & $12-26$ & 6 & 49 & 45 & silty clay & 0.12 & 1.09 \\
\hline & $\mathrm{B} 2 \mathrm{~g}$ & $26-48$ & 10 & 50 & 40 & silty clay & 0.20 & 1.25 \\
\hline & $\mathrm{C} 1 \mathrm{~g}$ & $48-72$ & 11 & 60 & 29 & silty clay & 0.17 & 2.56 \\
\hline & $\mathrm{C} 2 \mathrm{~g}$ & $72-100$ & 13 & 60 & 27 & silty clay & 0.21 & 2.48 \\
\hline \multirow[t]{5}{*}{ Naraibag } & Apg & $0-20$ & 11 & 40 & 49 & clay & 0.26 & 0.82 \\
\hline & $\mathrm{B} 2 \mathrm{~g}$ & $20-38$ & 11 & 38 & 51 & clay & 0.29 & 0.75 \\
\hline & B3g & $38-60$ & 12 & 46 & 42 & silty clay & 0.26 & 1.10 \\
\hline & $\mathrm{C} 1 \mathrm{~g}$ & $60-80$ & 10 & 35 & 55 & clay & 0.30 & 0.58 \\
\hline & $\mathrm{C} 2 \mathrm{~g}$ & $80+$ & 11 & 42 & 47 & silty clay & 0.26 & 0.89 \\
\hline \multirow[t]{6}{*}{ Jalkundi } & Aplg & $0-10$ & 8 & 42 & 50 & clay & 0.19 & 0.84 \\
\hline & Ap2g & $10-15$ & 15 & 43 & 42 & silty clay & 0.35 & 1.02 \\
\hline & B21g & $15-40$ & 20 & 48 & 32 & silty clay loam & 0.42 & 1.5 \\
\hline & B22g & $40-67$ & 20 & 51 & 29 & silt loam & 0.49 & 2.13 \\
\hline & $\mathrm{B} 23 \mathrm{~g}$ & $67-90$ & 22 & 43 & 35 & clay loam & 0.51 & 1.23 \\
\hline & $\mathrm{IICg}$ & $90+$ & 22 & 33 & 45 & clay & 0.67 & 0.75 \\
\hline \multirow[t]{5}{*}{ Siddirganj } & Apg & $0-20$ & 15 & 23 & 62 & clay & 0.65 & 0.37 \\
\hline & B2g & $20-30$ & 12 & 31 & 57 & clay & 0.39 & 0.54 \\
\hline & B3g & $30-54$ & 15 & 28 & 57 & clay & 0.54 & 0.42 \\
\hline & $\mathrm{IICg}$ & $54-74$ & 15 & 25 & 60 & clay & 0.60 & 0.41 \\
\hline & IIC2g & $74-100$ & 15 & 30 & 55 & clay & 0.50 & 0.55 \\
\hline \multirow[t]{5}{*}{ Tippera } & Apg & $0-12$ & 25 & 52 & 23 & silt loam & 0.45 & 2.26 \\
\hline & B1g & $12-26$ & 25 & 53 & 22 & silt loam & 0.47 & 2.41 \\
\hline & B21g & $26-46$ & 23 & 56 & 21 & silt loam & 0.41 & 2.67 \\
\hline & B22g & $46-76$ & 25 & 50 & 25 & silt loam & 0.50 & 2.00 \\
\hline & $\mathrm{C} 1 \mathrm{~g}$ & $76-100$ & 25 & 53 & 22 & silt loam & 0.47 & 2.41 \\
\hline Mean & & - & 14 & 41 & 45 & - & 0.34 & 0.91 \\
\hline
\end{tabular}

Geographically the seasonally flooded soils of Bangladesh including the studied soils belong to the Typic, Aquic, Aeric and Vertic subgroups based on texture and hydromorphic properties. In great group level these hydromorphic soils are Aquepts (with 
Table 3. Chemical properties of the seasonally flooded soils of Bangladesh.

\begin{tabular}{|c|c|c|c|c|c|c|c|c|c|c|c|}
\hline \multirow{2}{*}{$\begin{array}{l}\text { Depth } \\
(\mathrm{cm})\end{array}$} & \multicolumn{2}{|c|}{$\mathrm{pH}$} & \multirow[t]{2}{*}{$\Delta \mathrm{pH}^{*}$} & \multirow{2}{*}{$\begin{array}{c}\text { Organic } \\
\text { matter } \\
(\%)\end{array}$} & \multirow{2}{*}{$\begin{array}{c}\text { Total } \\
\mathrm{N} \\
(\%)\end{array}$} & CEC & $\mathrm{Ca}^{++}$ & $\mathrm{Mg}^{++}$ & $\mathrm{Na}^{+}$ & $\mathrm{K}^{+}$ & \multirow[t]{2}{*}{ BSP** } \\
\hline & $\mathrm{H}_{2} \mathrm{O}$ & $\mathrm{KCl}$ & & & & \multicolumn{5}{|c|}{$\mathrm{cmol}(\mathrm{p}+) / \mathrm{kg}$} & \\
\hline \multicolumn{12}{|c|}{ Arial soil series } \\
\hline $0-20$ & 6.8 & 6.1 & -0.7 & 2.05 & 0.16 & 29.5 & 19.5 & 6.1 & 0.75 & 0.42 & 90 \\
\hline $20-60$ & 6.5 & 5.8 & -0.7 & 1.85 & 0.13 & 33.0 & 22.0 & 6.9 & 0.67 & 0.44 & 91 \\
\hline $60-100$ & 6.8 & 6.0 & -0.8 & 1.56 & 0.11 & 15.8 & 10.0 & 2.7 & 0.42 & 0.24 & 84 \\
\hline $100+$ & 6.9 & 5.9 & -1.0 & 1.39 & 0.12 & 17.5 & 9.5 & 2.4 & 0.45 & 0.23 & 72 \\
\hline \multicolumn{12}{|c|}{ Debidwar soil series } \\
\hline $0-12$ & 5.9 & 5.7 & -0.2 & 2.01 & 0.12 & 13.6 & 6.5 & 3.1 & 0.87 & 0.31 & 83 \\
\hline $12-26$ & 7.0 & 6.7 & -0.3 & 1.72 & 0.08 & 12.3 & 6.5 & 3.6 & 0.21 & 0.15 & 88 \\
\hline $26-48$ & 7.0 & 6.6 & -0.4 & 0.96 & 0.06 & 12.0 & 6.5 & 3.5 & 0.22 & 0.14 & 89 \\
\hline $48-72$ & 6.8 & 6.6 & -0.2 & 0.58 & 0.05 & 9.0 & 3.5 & 2.4 & 0.35 & 0.08 & 75 \\
\hline $72-100$ & 6.8 & 6.2 & -0.6 & 0.48 & 0.05 & 9.6 & 4.0 & 2.7 & 0.16 & 0.07 & 79 \\
\hline \multicolumn{12}{|c|}{ Naraibag soil series } \\
\hline $0-20$ & 6.2 & 6.0 & -0.2 & 1.99 & 0.15 & 18.6 & 9.5 & 2.4 & 0.85 & 0.20 & 69 \\
\hline $20-38$ & 6.6 & 6.2 & -0.4 & 1.65 & 0.10 & 14.4 & 7.5 & 2.7 & 0.89 & 0.17 & 78 \\
\hline $38-60$ & 6.5 & 6.0 & -0.5 & 1.12 & 0.08 & 15.9 & 9.0 & 3.3 & 0.92 & 0.15 & 84 \\
\hline $60-80$ & 6.5 & 5.9 & -0.6 & 0.77 & 0.07 & 20.8 & 12.5 & 5.1 & 0.83 & 0.23 & 89 \\
\hline $80+$ & 6.5 & 6.2 & -0.3 & 0.60 & 0.05 & 12.7 & 8.0 & 2.5 & 0.76 & 0.16 & 89 \\
\hline \multicolumn{12}{|c|}{ Jalkundi soil series } \\
\hline $0-10$ & 5.9 & 5.4 & -0.5 & 1.92 & 0.19 & 18.9 & 9.5 & 3.5 & 1.00 & 0.24 & 76 \\
\hline $10-15$ & 6.7 & 6.4 & -0.3 & 1.62 & 0.08 & 12.5 & 7.5 & 2.2 & 0.75 & 0.12 & 84 \\
\hline $15-40$ & 6.6 & 6.1 & -0.5 & 0.65 & 0.05 & 12.3 & 6.5 & 2.1 & 0.85 & 0.11 & 77 \\
\hline $40-67$ & 6.6 & 5.8 & -0.8 & 0.48 & 0.05 & 11.6 & 7.0 & 2.3 & 0.81 & 0.13 & 88 \\
\hline $67-90$ & 6.6 & 5.6 & -1.0 & 0.48 & 0.04 & 12.6 & 8.0 & 2.7 & 0.65 & 0.10 & 90 \\
\hline $90+$ & 6.6 & 5.4 & -1.2 & 0.60 & 0.05 & 14.4 & 8.5 & 3.4 & 0.77 & 0.18 & 89 \\
\hline \multicolumn{12}{|c|}{ Siddirganj soil series } \\
\hline $0-20$ & 5.9 & 5.6 & -0.3 & 1.97 & 0.19 & 16.8 & 7.5 & 2.0 & 0.59 & 0.21 & 61 \\
\hline $20-30$ & 6.6 & 6.4 & -0.2 & 1.67 & 0.08 & 12.0 & 6.0 & 1.9 & 0.52 & 0.17 & 71 \\
\hline $30-54$ & 6.5 & 6.2 & -0.3 & 0.62 & 0.06 & 9.3 & 4.5 & 1.8 & 0.57 & 0.16 & 75 \\
\hline $54-74$ & 6.2 & 5.8 & -0.4 & 0.45 & 0.05 & 10.8 & 5.5 & 2.1 & 0.70 & 0.18 & 78 \\
\hline $74-90+$ & 6.2 & 5.1 & -0.8 & 0.65 & 0.06 & 16.6 & 9.0 & 3.6 & 0.60 & 0.28 & 81 \\
\hline \multicolumn{12}{|c|}{ Tippera soil series } \\
\hline $0-12$ & 5.4 & 5.0 & -0.4 & 1.76 & 0.11 & 11.1 & 5.5 & 1.5 & 0.22 & 0.20 & 67 \\
\hline $12-26$ & 6.2 & 5.4 & -0.8 & 1.46 & 0.09 & 11.1 & 5.5 & 3.7 & 0.35 & 0.10 & 87 \\
\hline $26-46$ & 6.2 & 5.4 & -0.8 & 0.62 & 0.06 & 10.5 & 5.0 & 4.3 & 0.41 & 0.15 & 93 \\
\hline $46-76$ & 6.2 & 5.5 & -0.7 & 0.53 & 0.05 & 11.0 & 4.5 & 4.4 & 0.58 & 0.11 & 86 \\
\hline $76-100$ & 6.4 & 5.2 & -1.2 & 0.58 & 0.05 & 11.4 & 5.5 & 4.0 & 0.59 & 0.14 & 89 \\
\hline Mean & 6.5 & 5.9 & -0.5 & 0.88 & 0.09 & 14.9 & 8.2 & 3.2 & 0.60 & 0.19 & 82 \\
\hline
\end{tabular}

$* \Delta \mathrm{pH}=\mathrm{pH}(\mathrm{KCl})-\mathrm{pH}\left(\mathrm{H}_{2} \mathrm{O}\right) ; *$ BSP= Base saturation per cent.

Cambic horizon) or Aquents (without Cambic horizon). The other characteristics of tropical soils e.g. segregation of iron, in situ development of Oxic characteristics could not develop in these soils because of the time factor and prolonged seasonal inundation. On 
the contrary signs of gleization particularly in subsoil characteristics are clearly visible in these soils. ${ }^{(8)}$ The seasonally flooded soils of Bangladesh are presently puddled using the mechanical or traditional ploughs to cultivate transplanted paddy.(5) Consequently, paddy straws are smeared in the topsoil in large quantity. Due to addition of paddy straw having wide $\mathrm{C} / \mathrm{N}$ ratio the microbial activities in topsoil are augmented as the microbes can derive adequate energy from the added paddy straw. The phenomenon depletes the soil nitrogen content as the microbes derive the needed nitrogen for cell formation from the soil humus.

The organic matter contents in the hydromorphic alluvial soils of Bangladesh as in other tropical soils, even though a lithological feature declines with depth, but do not reach beyond 0.2 per cent level within $1.5 \mathrm{~m}$ depth. The relatively higher content of organic matter in the topsoil of the studied soil series are due to the reasons stated above help support the natural fertility of these soils.

The total contents of nitrogen in the studied soils range between 0.05 and 0.19 per cent with an average of 0.09 per cent (Table 3). The Jalkundi and Siddirganj series have the highest contents of nitrogen than the Tippera series. In all the soil series the content of nitrogen decreases regularly with depth like that of organic matter. Mazumder et al.(16) also reported similar trend for some seasonally flooded Brahmaputra floodplain soils.

The CEC of these soils based on texture ranges from 9.0 to $33.0 \mathrm{cmol}(\mathrm{p}+) / \mathrm{kg}$ with a mean value of $14.9 \mathrm{cmol}(\mathrm{p}+) / \mathrm{kg}$ (Table 3) showing a highly significant positive correlation with clay $\left(\mathrm{r}=+67^{* *}\right)$ and organic matter $\left(\mathrm{r}=+59^{* *}\right)$ contents. Obviously $\mathrm{Ca}^{2+}$ is the dominant cation in the colloidal complex followed by $\mathrm{Mg}^{2+}, \mathrm{Na}^{+}$and $\mathrm{K}^{+}$(Table 3). The high $\mathrm{Ca}^{2+} / \mathrm{Mg}^{2+}$ is an indication of a weak type of hydromorphism in these soils.(4) The BSP based on $\mathrm{pH}$ values that ranged between 61 to 93 indicate high content of basic nutrients in these soils. In Bangladesh varying doses of chemical fertilizers are added to soils to supplement the shortfall of nutrient elements present for growing the HYV rice. The high nutrient holding capacity of the seasonally flooded soils depend primarily on high CEC that controls the adsorption capacity of nutrient ions.

The available nitrogen in topsoils ranges from 104 to $140 \mathrm{mg} / \mathrm{kg}$, available phosphorus content ranges from 6 to $8 \mathrm{mg} / \mathrm{kg}$ while available potassium content ranges from 78 to $168 \mathrm{mg} / \mathrm{kg}$ (Table 4). Mineralogical studies revealed that the seasonally flooded soils, particularly the ones developed in Ganges floodplain sediments contain adequate quantity of weatherable minerals like feldspar and biotite have high potential to release $\mathrm{K}^{+}$nutrient.(17) However, the high content of smectite present in the soils have the potentiality to fix large quantity of added $\mathrm{K}^{+}$fertilizer during each dry season. The quantity of $\mathrm{K}^{+}$fixed by every year by soil minerals is needed to be determined through research.

DTPA-extractable Fe contents in the studied soils ranged from 73 to $131 \mathrm{mg} / \mathrm{kg}$ (Table 4). Prolonged submergence coupled with reducing conditions are reported to be 
the reasons for higher available Fe contents. Considering $4.5 \mathrm{mg} / \mathrm{kg}$ soil as the thresold value of DTPA-extractable $\mathrm{Fe}$, ${ }^{(14)}$ all the studied soils have more than sufficient quantities of available Fe.

Table 4. Nutrient elements in the surface horizon of some seasonally flooded soils.

\begin{tabular}{|c|c|c|c|c|c|c|c|c|}
\hline \multirow[t]{2}{*}{ Soil series } & \multicolumn{4}{|c|}{ Available $(\mathrm{mg} / \mathrm{kg})$} & \multicolumn{4}{|c|}{ DTPA- extractable $(\mathrm{mg} / \mathrm{kg})$} \\
\hline & $\mathrm{N}$ & $\mathrm{P}$ & $\mathrm{K}$ & $\mathrm{S}$ & $\mathrm{Fe}$ & $\mathrm{Mn}$ & $\mathrm{Cu}$ & $\mathrm{Zn}$ \\
\hline Arial & 140 & 8 & 164 & 27 & 128 & 55 & 5.0 & 2.0 \\
\hline Debidwar & 106 & 7 & 121 & 18 & 78 & 56 & 2.2 & 1.6 \\
\hline Naraibag & 136 & 8 & 78 & 21 & 131 & 80 & 4.2 & 2.8 \\
\hline Jalkundi & 118 & 7 & 94 & 23 & 90 & 87 & 3.7 & 2.5 \\
\hline Siddirganj & 110 & 6 & 82 & 11 & 98 & 34 & 2.0 & 1.8 \\
\hline Tippera & 104 & 6 & 78 & 10 & 73 & 39 & 2.0 & 1.2 \\
\hline Mean & 119 & 7 & 103 & 18 & 100 & 58 & 3.2 & 2.0 \\
\hline
\end{tabular}

The DTPA-extractable Mn contents in the studied soils vary widely ranging from 34 to $87 \mathrm{mg} / \mathrm{kg}$. Lindsay and $\mathrm{Cox}^{(18)}$ identified $\mathrm{pH}$ as the key factor that influences $\mathrm{Mn}$ availability in soils. Taking $3.0 \mathrm{mg} / \mathrm{kg}$ DTPA-Mn in soils as the critical limit,(19) it can be safely concluded that the studied soils contain more than adequate quantity of available $\mathrm{Mn}$. The DTPA-extractable $\mathrm{Cu}$ in the studied soils varied from 2 to $5 \mathrm{mg} / \mathrm{kg}$ (Table 4). Katyal and Sharma ${ }^{(20)}$ reported similar result in soils having aquic moisture regimes. Considering the $0.2 \mathrm{mg} / \mathrm{kg}$ of DTPA-extractable $\mathrm{Cu}$ as critical limit ${ }^{(14)}$ the available $\mathrm{Cu}$ contents in the studied soils are adequate. The extractable $\mathrm{Zn}$ content in the studied soil series varied between 1.2 and $2.8 \mathrm{mg} / \mathrm{kg}$ (Table 4). The observed results agree with the ones reported by Hassan ${ }^{(21)}$ and Khan et al. ${ }^{(22)}$ Taking $0.8 \mathrm{mg} / \mathrm{kg}$ as the critical limit for extractable $\mathrm{Zn},(14,19)$ the studied soils series contained available $\mathrm{Zn}$ above the threshold value.

The biggest problem in the management of seasonally flooded soils of Bangladesh is their annual inundation. The flooding imposes a serious restriction on cropping patterns. Unpredictable flush floods sometimes cause total damage to the existing crops in the field. There is uncertainty in the arrival and recession of flood water which impair the management plan of these soils.

Texturally these soils are fine-grained having high moisture retention capacity. ${ }^{(8)}$ This helps in countering the ill-effects of short droughts. However, if there is any long drought there will be permanent damage to the growing crops. Nutrient availability for plants are linked with the type and amount of clay minerals and organic matter contents that regulates the CEC. The high CEC of the studied soils indicate a strong nutrient holding capacity. This helps in decreasing the loss of nutrients with the receding flood water. Because of flooding there is gain in nutrients as well coming in the sediments and flood water. 
Formation of plough pan - a compact slowly permeable layer - below the Ap horizon has been formed due to puddling by using traditional ploughs to which the soils were subjected to for transplanted paddy cultivation. The plough pan being less permeable and compact is favourable for transplanted paddy cultivation but this compact layer restricts penetration of crop root below to harness moisture and nutrients present in the lower layers. Slightly acidic to neutral soil reaction and high BSP provide a congenial chemical environment for crop production in these soils (Tables 3 - 4). The presently studied soils in Bangladesh are subjected to seasonal inundation on the basis of which these wetland soils are separated from the viewpoint of land use potentials. Other physical limitations experienced by these soils are seasonal droughtiness, potential erosion hazards, shortage of nutrients, irregular relief condition, toxicity and sudden wetness by flush floods.

Finally it must be noted that because of multiple cropping the problem of nutrient shortage and loss have developed in these seasonally flooded soils. Researches have shown that the quantities of nutrient elements from the soil system per hectare to produce the stated quantity of rice is $45 \mathrm{Kg} \mathrm{N}, 25 \mathrm{Kg} \mathrm{P} \mathrm{O}_{5}$ and $70 \mathrm{Kg} \mathrm{K}_{2} \mathrm{O}$ while the quantites of nutrient elements added to the soil system per each transplanted HYV paddy (boro and aman) are $100 \mathrm{Kg} \mathrm{N}, 35 \mathrm{Kg} \mathrm{P}_{2} \mathrm{O}_{5}$ and $45 \mathrm{Kg} \mathrm{K}_{2} \mathrm{O}$.(23) The quantity of nitrogenous fertilizer added in excess to the soil system is lost due to volaltilization, leaching, run-off and/or consumed due to growth of weeds while the excess quantities of phosphates and potash either get fixed in the soil system or remain as residues. Proper and scientific management of soil health and their sustained productivity can be maintained through balancing the incoming nutrients due to fertilizer addition, biological fixation, weathering of biotite and feldspar minerals, precipitation of thunder storms and decomposition of organic residues and the outgoing with the volatilization, etcetra. The soil properties though have roles in the management of soil but that only contribute if and when all the above factors are duly taken into consideration.

\section{References}

1. Ramsar Convention Bureau 2000. Ramsar Handbooks for the Wise Use of Wetlands. Gland, Switzerland.

2. Brinkman R 1977. Surface-water gley soils in Bangladesh: Genesis. Geoderma 3: 199-206.

3. Kawaguchi K and K Kyuma 1969. Lowland Rice Soils in Thailand. The Centre for Southeast Asian Studies. Tokyo University, Japan. p. 270.

4. Hussain MS and D Swindale 1970. A morphological and mineralogical study of the Gray Hydromorphic soils of the Hawaian Islands. Pacific Sci. 24: 543-553.

5. Brammer H 1996. The Geography of the Soils of Bangladesh. The University Press Limited, Dhaka, Bangladesh. p. 287.

6. Miah MM 1988. Floods in Bangladesh. Academic Publishers, Dhaka. p. 107. 
7. Ponnamperuma FN 1985. Chemical kinetics of wetland rice soil relative to soil fertility. In: Wetland Soils-Characterizatoin, Classification and Utilization. International Rice Research Institute (IRRI), Los Banos, Philippines.

8. Akter KF, MS Hussain and ZH Khan 2004. Morphological and clay mineralogical characteristics of some seasonally flooded soils of Bangladesh. J. Asiatic Soc. Bangladesh Sci. 30(2): 11-22.

9. Gee, GW and JW Bauder 1986. Particle size analysis. In: Methods of Soil Analysis. Part 1. $2^{\text {nd }}$ ed. A Klute (ed.) Agronomy 9: 383-411.

10. Walkley A and IA Black 1934. An examination of the Degtijareff method for determining soil organic matter and a proposed modification of the chromic acid titration method. Soil Sci. 37: 29-38.

11. Bremner JM and CS Mulvary 1982. Nitrogen-Total. In: Methods of Soil Analysis. Part 2. $2^{\text {nd }}$ ed. AL Page, RH Miller and DR Keeney (eds.) Agronomy 9: 595-624.

12. Rhoades JD 1982. Cation exchange capacity. In: Methods of Soil Analysis. Part 2. $2^{\text {nd }}$ ed. AL Page, RH Miller and DR Keeney (eds.) Methods of Soil Analysis. Part 2 (2nd ed.). Agronomy 9: 149-157.

13. Jackson ML 1967. Soil Chemical Analysis. Prentice Hall of India Pvt. Ltd. New Delhi.

14. Lindsay WL and WA Norvell 1978. Development of a DTPA soil test for zinc, iron, manganese and copper. Soil Sci. Soc. Am. J. 42: 421-428.

15. SRDI Staff 1965-1986. Reconnaissance soil survery reports of different districts of Bangladesh. Soil Resources Development Institute (SRDI). Farmgate, Dhaka.

16. Mazumder AR, ZH Khan, MS Hussain, ASM Mohiuddin and B Faiz 2003. A study of nutrient contents in some representative soils from the Brahmaputra floodplain in Bangladesh. J. Asiat. Soc. Bangladesh, Sci. 29(2):79-90.

17. Huizing HGJ 1971. A reconnaissance study of the mineralogy of sand fractions from East Pakistan sediments and soil. Geoderma 6: 109- 133.

18. Lindsay WL and FR Cox 1985. Micronutrient soil testing for the tropics. In: P.L.G. Vlek (ed.). Micronutrients in Tropical Food Crop Production. Fert. Res. 7: 169-200.

19. BARC 2005. Fertilizer Recommendation Guide. Bangladesh Agricultural Research Council (BARC). Dhaka, Bangladesh.

20. Katyal JC and BD Sharma 1991. DTPA-extractable and total $\mathrm{Zn}, \mathrm{Cu}, \mathrm{Mn}$ and $\mathrm{Fe}$ in Indian soils and their association with some soil properties. Geoderma 49: 165-179.

21. Hassan MM 1991. Zn, Cu, Mn and Co contents in some soils of Bangladesh. J. Indian Soc. Soil Sci. 39:73-77.

22. Khan ZH, AR Mazumder, MS Hussain, SM Saheed and ASM Mohiuddin 1997. Total and DTPA-extractable Fe, Mn, $\mathrm{Cu}$ and $\mathrm{Zn}$ contents in some soils of Bangladesh. J. Indian Soc. Soil Sci. 45(3): 485-489.

23. BBS 2007. Statistical Year Book of Bangladesh. Bangladesh Bureau of Statistics. Govt. of Bangladesh, Dhaka.

24. Soil Survey Staff 1999. Soil Taxonomy - A basic system of soil classification for making and interpreting soil surveys. 2nd ed. USDA. Handbook No. 436. US Government Printing Office, Washington, D.C. 